\title{
EFFECT OF SALINITY AND SOME BIO-COMPOUNDS ON GROWTH, ESSENTIAL OIL YIELD AND CHEMICAL COMPOSITION OF MARJORAM PLANTS
}

Massoud, Hekmat Y.*;M. N. Shalan ${ }^{\star *} ;$ K. M. El-Hindi ${ }^{\star}$ and

A. E. E Dapour ${ }^{\star}$

* Veget. and Flori., Dept., Fac. Agric., Mansoura Univ.

** Medicinal and Aromatic Plants, Res. Dept., Hort. Res. Inst., ARC, Egypt.

\begin{abstract}
Two field experiments were carried out at Baramoon Experimental Station, Dakahlia Governorate, Egypt, during the two successive seasons of 2006/2007 and 2007/2008 to study the marjoram (Majorana hortensis Mnch) potential to survive under salinity condition and to find out the effect of some bio-fertilizers on this potential. The present investigation were planed to test (4) levels $(0,2000,4000$ and $6000 \mathrm{ppm}$ ) of saline water irrigation, as well as foliar nutrition of some bio-compounds i.e., (EM), Novatrein and Askobein as mixtures and their interactions on plant growth, essential oil, quantity and quality of marjoram.

Marjoram plants showed a quite tolerance to salinity at $2000 \mathrm{ppm}$, whereas the excess concentrations( 4000 and 6000 ppm) caused a severe damage to the irrigated plants. A remarked reduction in fresh and dry weights of plant, survival percentage, essential oil percentage and its components under different salinity concentrations. Gas Liquid Chromatography showed that saline water irrigation at levels of 2000 and $4000 \mathrm{ppm}$ slightly decreased the percentages of main components whereas 6000 ppm caused vanishing of some constituents and caused severe harmful to oil principals.

All bio-compounds i.e., (EM) and both of Novatrein or Askobein, slightly caused significant increments in the plant growth characters and displayed the best estimates in the two seasons. Application of these compounds raised the plant potential to tolerate salinity and simulation increased the survival percentage. In addition, utilizing these compounds slightly increased oil active principals and could overcome the harmful effect of saline irrigation water.
\end{abstract}

\section{INTRODUCTION}

Sweet marjoram (Majorana hortensis, Mnch.), Fam. Lamiaceae is an important aromatic and medicinal plant. The sweet marjoram (Majorana hortensis ,Mnch), indigenous to the Mediterranean region. The plant is cultivated in Germany, Hungary, France, Tunisia, especially in Bulgaria, and small cops are planted in the united state. In Egypt, it is considered as an important economic agricultural export crop, it grows well and widely particularly in Upper Egypt. Dried marjoram and the oil are used as spices in the food industry, as well as for their preservative and medicinal properties. It used as carminative and stimulant and is greatly used for confectionery, tooth pastes and whooping cough.

Several investigators studied the effect of different levels of salinity on the growth, essential oil percentage and constituents of several medicinal and aromatic plants. 
Hussein (1999) studied the effect of salinity levels on some varieties of Ocimum basilicum. He found that the level of salinity (1500 ppm) caused an increase in plant height, number of leaves/plant, fresh and dry weight of leaves as well as oil percentage and content in Ocimum basilicum var. Purpurascens.

Thereupon, under deficiency of water, irrigation with saline water is the mainly available source in many parts of newly reclaimed areasln the same time, under the arid climatic conditions prevailing in Egypt the perennial irrigation practices, association with imperfect drainage system, continuously cause an increase of tap water levels and the relatively high salinity levels of water sources particularly in the new reclaimed desert land. This salinity of soils is rapidly going to be an acute problem,( El-Queseni and El-Gayar, 1993).

Soil salinity disrupts several physiological processes in plant lead to reduction in growth. Therefore, the need for protecting such plants is in demand. This can achieved throughout selecting superior species, which its plant has a high survival capability against soil and water salinity. The useful usages of plant foliar spray with certain trace elements such as iron, manganese and zinc have recently overcome the low tolerance to salinity and minimize salinity injuries ( Hasegawa et al., 1986).

Several workers tended to utilize natural and biofertilizer instead of chemical compounds to avoid the side effects of the latter substances for medicinal, food and aromatic plants, (EM) is another mixture containing photosynthetic bacteria, lactic acid producing bacteria and yeast. (EM) is used to evaluate its effect for overcome harmful salinity.

The use of microelements to improve the yield and the active ingredients of medicinal and aromatic plants is considered as one of the most important and interested research subjects.

Omar et al., (1983) on anise plants indicated that the high doses of $\mathrm{Zn}$ and $\mathrm{Mn} 3 \mathrm{gm} / \mathrm{liter}$ had expressed the highest significant effect on fruit yield per plant, the essential oil and/or fixed oil yield per plant.

Harridy (1986) found that, $\mathrm{Zn}$ at (100 ppm) increased significantly the dry matter of periwinkle plants.

As for micro-elements, it was found that, growth characters in terms of plant height, branches number and dry weight as well as the yield of chamomile flower significantly increased by using foliar spray of $\mathrm{Zn}, \mathrm{Mn}$ and Fe singly or in combinations,( Makarim and Bishr .,1988).

The present research was carried out to study the effect of different levels of salinity on growth and oil yield of marjoram and how to overcome the harmful of high level of salinity by using some nutritional compounds.

\section{MATERIALS AND METHODS}

The present work was carried out during the two successive seasons of 2006/2007 and 2007/2008 at the Experimental Farm in Baramoon, Dakahlya Governorate. Cuttings of marjoram (Majorana hortensis,Mnch.) 
were taking from symmetry mother plants grown in the Medicinal and Aromatic Plants Farm in the Agriculture Research Center, in Giza.

The plant cuttings were planted in nursery under shaded conditions for rooting on Oct .15th in the two seasons 2006/2007 and 2007/2008.

On Feb. $15^{\text {th }}$ the rooted cuttings were individually transplanted in plastic bags of $25 \times 35 \mathrm{~cm}$; each bag was filled with $4.5 \mathrm{~kg}$ of air dried soil, which it was $2: 1$ clay : sand by volume. Each bag had one plant sample (about $10 \mathrm{~cm}$ in height). The mechanical and chemical properties of soil are shown in Table $(A)$.

Table (A): Mechanical and chemical analysis of the used experimental soil .

\begin{tabular}{|c|c|c|c|c|c|}
\hline \multicolumn{2}{|c|}{ Mechanical analysis } & \multicolumn{2}{|c|}{ Chemical analysis } & \multirow{2}{*}{\multicolumn{2}{|c|}{$\begin{array}{c}\text { Soluble cations and anions } \\
\text { Cations (meq/100 g soil) }\end{array}$}} \\
\hline Sand (\%) & 15.32 & Available N (ppm) & 43.61 & & \\
\hline Silt (\%) & 34.96 & Available P (ppm) & 9.00 & $\mathrm{Ca}^{++}$ & 0.49 \\
\hline Clay (\%) & 45.12 & Available K (ppm) & 356 & $\mathrm{Mg}^{++}$ & 0.37 \\
\hline \multirow[t]{7}{*}{ Soil type } & clayed & Organic matter (\%) & 1.68 & $\mathrm{Na}^{+}$ & 0.39 \\
\hline & & EC \% & 0.12 & $\mathrm{~K}^{+}$ & 0.03 \\
\hline & & $\mathrm{pH}$ & 7.75 & \multicolumn{2}{|c|}{ Anions (meq/100 g soil) } \\
\hline & & $\mathrm{CaCO3}$ & 2.33 & $\mathrm{CO}_{3}{ }^{---}$ & 0.02 \\
\hline & & & & $\mathrm{HCO}_{3}^{-}$ & 0.52 \\
\hline & & & & $\mathrm{SO}_{4}^{--}$ & 0.48 \\
\hline & & & & $\mathbf{C l}-$ & 0.26 \\
\hline
\end{tabular}

Plants were held under natural conditions and irrigated with tap water and foliar sprayed with $3.5 \mathrm{~g}$ super phosphate $(15.5 \%)$ and $1.25 \mathrm{~g}$ potassium sulphate $(48 \%)$ per bag.All plants received normal agricultural practices.

The plant samples were treated after 4 weeks from transplanting date with the irrigation of saline water and foliar sprayed with treatments EM, Novatrein and Askobein.

I-Saline water irrigation treatments:

Four levels of artificial saline water were used; these levels were tap water of 304 ppm as Control, 2000; 4000 and 6000ppm.

Saline solution was prepared from mixture of 2:1 sodium and calcium both in chloride, respectively. The bags were irrigated with tape water for four weeks before irrigated with the saline water. Irrigation water was applied to raise the soil moisture content up to the field capacity with $15 \%$ excess as leaking fraction to avoid salt accumulation in the bags.

II. (Biofertilizers):

Effective microorganism (EM):

$(E M)$ is a natural combination of beneficial microbes using in Agriculture, Horticulture and Waste management. The benefits of Nature farming (EM) consists of mixed cultures of beneficial and natural occurring microorganisms can be applied as inoculants to increase the microbial diversity of soils and plants.

EM contains:

1. Lactic acid bacteria.

2. Yeast.

3. Photosynthetic bacteria. 
4. Actinomycetes.

5. Types of microorganisms .

III. (Chemical fertilizers):

(a) Novatrein(Nov):

Novatrein as a product of Agricultural ministry contains macro-and microelements such as nitrogen $5 \%, \mathrm{P}_{2} \mathrm{O}_{5} 5 \%, \mathrm{~K}_{2} \mathrm{O}_{5} \%$, iron EDTA (Fe 15 $\%)$, manganese EDTA (Mn $10 \%)$, zinc EDTA (Zn $15 \%)$, boron (B 0.05\%) and molybdenum (Mo 0.02\%).

\section{(b)Askobein(Ask):}

Natural growth activator as a product of Agricultural ministry contains nutritional organic substances (nearly $62 \%$ ) for acceleration of plant growth. The active substances of Askobein are Ascorbic acid +citric acid nearly $38 \%$. Treatments were conducted as following:-

The plants received the different treatments at Mar.15th (one month late after transplanting) for the two seasons of 2006/2007 and 2007/2008. The treatments were as following:

1- Control tap water (304ppm).

2- Saline water at level (2000 ppm).

3- Saline water at level $(4000 \mathrm{ppm})$.

4- Saline water at level (6000ppm).

5- $(2000 \mathrm{ppm})+\mathrm{EM}\left(1 \mathrm{~cm}^{3} / \mathrm{L}\right)+$ Novatrein $\left(3 \mathrm{~cm}^{3} / \mathrm{L}\right)$.

6- $(2000 \mathrm{ppm})+\mathrm{EM}\left(1 \mathrm{~cm}^{3} / \mathrm{L}\right)+$ Askobein $(1 \mathrm{~g} / 3 / 4 \mathrm{~L})$.

7- $(2000 \mathrm{ppm})+\mathrm{EM}\left(1 \mathrm{~cm}^{3} / \mathrm{L}\right)+$ Novatrein $\left(3 \mathrm{~cm}^{3} / \mathrm{L}\right)+$ Askobein $(1 \mathrm{~g} / 3 / 4 \mathrm{~L})$.

8- $(4000 \mathrm{ppm})+\mathrm{EM}\left(1 \mathrm{~cm}^{3} / \mathrm{L}\right)+$ Novatrein $\left(3 \mathrm{~cm}^{3} / \mathrm{L}\right)$.

9- $(4000 \mathrm{ppm})+\mathrm{EM}\left(1 \mathrm{~cm}^{3} / \mathrm{L}\right)+$ Askobein $(1 \mathrm{~g} / 3 / 4 \mathrm{~L})$.

10- $(4000 \mathrm{ppm})+\mathrm{EM}\left(1 \mathrm{~cm}^{3} / \mathrm{L}\right)+$ Novatrein $\left(3 \mathrm{~cm}^{3} / \mathrm{L}\right)+$ Askobein $(1 \mathrm{~g} / 3 / 4 \mathrm{~L})$.

11- $(6000 \mathrm{ppm})+\mathrm{EM}\left(1 \mathrm{~cm}^{3} / \mathrm{L}\right)+$ Novatrein $\left(3 \mathrm{~cm}^{3} / \mathrm{L}\right)$.

12- $(6000 \mathrm{ppm})+\mathrm{EM}\left(1 \mathrm{~cm}^{3} / \mathrm{L}\right)+$ Askobein $(1 \mathrm{~g} / 3 / 4 \mathrm{~L})$.

13- $(6000 \mathrm{ppm})+\mathrm{EM}\left(1 \mathrm{~cm}^{3} / \mathrm{L}\right)+$ Novatrein $\left(3 \mathrm{~cm}^{3} / \mathrm{L}\right)+$ Askobein $(1 \mathrm{~g} / 3 / 4 \mathrm{~L})$.

The experiment was complete randomized blocks design which contained 13 treatments, every treatment contained three replicates, each replicate contained five bags,

Harvesting:

The plants were harvested three times at $15^{\text {th }}$ of June, August and October in both seasons. The aerial parts of plants had harvested at $10 \mathrm{~cm}$ above surface of soil. Three cuts were collected in a two month_interval from June to October of the first and second year of plant age

1. Vegetative growth characters:

Nine plants were chosen randomly from each treatment and the following characters were recorded:

- Plant height $(\mathrm{cm})$ : It was measured from the surface of the ground to yhe tallest part of each plant.

- Number of branches.

- Fresh and dry weight of whole herb (g/plant).

N.B herb was dried in perforated paper bags at room temperature until constant weight. 


\section{Survival percentage:}

It was recorded two weeks before harvesting date (after all fertilization treatments were applied) as:-

Number of Survival plants / treatment

$$
\text { Survival } \%=\frac{\text { Number of Survival plants for control }}{\text { X } 100}
$$

\section{Essential oil percentage:}

The estimation of volatile oil was carried of fresh at cutting time. Plant samples $(100 \mathrm{~g})$ were extracted by hydro distillation in Clevenger apparatus according Egyption pharmacopia(1984).

4.Chemical structure of essential oil :

The Gas Liquid Chromatography (GLC) analysis was carried out at the Medicinal and Aromatic Plants Section,Agric.Res.Center to separate and identify the components of essential oil of marjoram herb. The constituents of the essential oil were identified by matching their retention time (RT) with those of authentic samples under the same conditions, according to Guenther and Joseph (1978).

\section{Statistical analysis:}

Data of the present study was statistically analyzed and the differences between the means of the treatments were considered significant when they were more than least significant differences (LSD) at the levels of $5 \%$ according to Steel and Torrie (1980).

\section{RESULTS AND DISCUSSION}

1. Effect of saline irrigation water, some nutritional compounds (EM1, Novatrein, Askobein) and their interactions on vegetative growth of marjoram plants :

1.1- plant height $(\mathrm{cm})$ :

It is evident from the data presented in Table (1) that saline water treatment, generally, decreased marjoram plant height compared to unsalinized control plants. This reduction in three cuts was significant under all salinity concentrations (2000, 4000 and $6000 \mathrm{ppm}$ ). Moreover, the reduction in plant height was increased as raising salinity levels at $6000 \mathrm{ppm}$. Similar reduction in marjoram plant height under salinity stress was recorded by Abd El-Kafie (1995) on Salvia officinalis L. and Shalan et al., (2006) on marjoram. On the same trend, the highest values was obtained at cases of interactions for EM + Novatrein combined with all salinity levels 2000, 4000 and $6000 \mathrm{ppm}$, respectively. Results were significant increase plant height compared to control plants in three cuts at both two seasons. Furthermore, increasing salinity level at $6000 \mathrm{ppm}$ under each level of EM + Novatrein caused different decreasing of plant height compared to control plants in three cuts. Also, it is clear from data that used combinations of (EM+Novatrein+Askobein) reduced the harmful effect of saline water treatments. It might be due to that using (EM) enhanced vegetative growth, leaf chlorophyll and improved soil structure, as mentioned by Abd El-Messeih et al., (2005). Moreover, Sangakkara (1999) reported that (EM) improved the nutrient uptake efficiency, enhanced root growth and 
increased yield. On the other hand, in addition of (EM) as biostimulant factor, Novatrein which consists of Macro and microelements caused increasing in plant height might be due to enhancing cell division and/or cell enlargement.

Table (1): Plant height (cm) of Majorana hortensis ,Mnch as affected by saline irrigation water, some nutritional compounds and their interactions during $2006 / 2007$ and $2007 / 2008$ seasons.

\begin{tabular}{|c|c|c|c|c|c|c|c|}
\hline \multirow{3}{*}{\multicolumn{2}{|c|}{ Treatments }} & \multicolumn{6}{|c|}{ Plant height (cm) } \\
\hline & & \multicolumn{3}{|c|}{ 1st season $2006 / 6007$} & \multicolumn{3}{|c|}{ 2nd season $2007 / 2008$} \\
\hline & & 1st cut & 2nd cut & 3rd cut & 1st cut & 2nd cut & 3rd cut \\
\hline \multicolumn{8}{|c|}{ Salinity (ppm) } \\
\hline \multicolumn{2}{|c|}{ Control * } & 43.66 & 46.71 & 37.90 & 44.23 & 48.62 & 39.20 \\
\hline \multicolumn{2}{|c|}{2000} & 42.60 & 45.53 & 36.85 & 43.30 & 47.63 & 37.98 \\
\hline \multicolumn{2}{|c|}{4000} & 40.56 & 43.41 & 34.73 & 41.28 & 45.61 & 35.70 \\
\hline \multicolumn{2}{|c|}{6000} & 35.61 & 38.70 & 32.01 & 36.33 & 40.60 & 33.62 \\
\hline \multicolumn{2}{|c|}{ L.S.D at $5 \%$} & 4.02 & 3.59 & 1.86 & 5.34 & 2.66 & 1.93 \\
\hline \multicolumn{8}{|c|}{ Interactions: } \\
\hline \multicolumn{2}{|c|}{\begin{tabular}{|c|} 
Control $^{*}$ \\
\end{tabular}} & 37.51 & 43.56 & 36.40 & 36.52 & 41.53 & 37.13 \\
\hline \multirow{3}{*}{$\begin{array}{l}(2000 \\
+\mathrm{EM})\end{array}$} & Nov. & 39.53 & 46.62 & 39.51 & 39.56 & 44.63 & 39.15 \\
\hline & Ask. & 42.62 & 48.51 & 41.82 & 41.66 & 46.72 & 42.31 \\
\hline & Nov. + Ask & 48.93 & 55.39 & 47.34 & 47.32 & 53.11 & 48.33 \\
\hline \multirow{3}{*}{$\begin{array}{l}(4000 \\
+ \text { EM) }\end{array}$} & Nov. & 38.23 & 44.60 & 37.51 & 38.34 & 43.92 & 37.62 \\
\hline & Ask. & 40.62 & 46.30 & 39.80 & 40.66 & 46.40 & 39.71 \\
\hline & Nov. + Ask & 45.56 & 53.36 & 45.20 & 45.43 & 52.38 & 45.62 \\
\hline \multirow{3}{*}{$\begin{array}{l}(6000 \\
+ \text { EM) }\end{array}$} & Nov. & 37.90 & 41.60 & 32.53 & 38.40 & 42.70 & 32.88 \\
\hline & Ask. & 39.00 & 42.63 & 34.67 & 39.63 & 43.60 & 34.60 \\
\hline & Nov. + Ask & 41.00 & 48.71 & 40.00 & 42.92 & 47.68 & 40.68 \\
\hline \multicolumn{2}{|c|}{ L.S.D at $5 \%$} & 3.76 & 4.11 & 2.09 & 6.98 & 5.07 & 2.33 \\
\hline
\end{tabular}

\subsection{Herb fresh and dry weights(g/plant):}

The results in Table (2) demonstrate that the lower level of saline water did not affect herb fresh weight/plant, while raising salinity in irrigation water up to 4000 or $6000 \mathrm{ppm}$ caused significant decrease in herb fresh weight comparing with control in both seasons.

The same was true increase of herb dry weight/plant, it was significantly reduced across all salinity concentrations comparing with unsalinized control plants as shown in Table (3). Similar reduction in herb fresh weight/plant was observed by Kandeel and Elwan (1991) on Majorana hortensis plants. The reduction in the herb characters might attributed to that salinity reduced the synthesis of organic matter in plant tissues. And it increase osmotic pressure of irrigation water which led to a reduction in water absorption by plants consequently reduced plant photosynthesis, Mandour et al., (1979).

As for the effect of trace-elements and other components in both of Novatrein, EM1 and Askobein, it is obvious from Tables (2) and (3) that previously mentioned treatments significantly increased both herb fresh and dry weights/plant.

The interactions between all of EM1 + Novatrein + Askobein recorded the highest valves followed by EM1 + Askobein , EM1 + Novatrein as foliar spraying on plants under stress of different salinity levels (2000, 4000 and $6000 \mathrm{ppm}$ ) comparing with the control plants during three cuts in both seasons. 
Table (2): Fresh weight of plant of Majorana hortensis, Mnch as affected by saline irrigation water, some nutritional compounds and their interactions during 2006/2007 and 2007/2008 seasons.

\begin{tabular}{|c|c|c|c|c|c|c|c|c|c|}
\hline \multirow{3}{*}{\multicolumn{2}{|c|}{ Treatments }} & \multicolumn{8}{|c|}{ Fresh weight of herb (g/plant) } \\
\hline & & \multicolumn{4}{|c|}{ 1st season $2006 / 6007$} & \multicolumn{4}{|c|}{ 2nd season 2007/2008 } \\
\hline & & \multicolumn{3}{|c|}{ 1st cut 2 2nd cut 3 3rd cut } & \multirow[t]{2}{*}{ Total } & \multicolumn{3}{|c|}{ 1st cut 2 2nd cut 3 3rd cut } & \multirow[t]{2}{*}{ Total } \\
\hline \multicolumn{8}{|c|}{ Salinity (ppm) } & & \\
\hline \multicolumn{2}{|c|}{ Control * } & 130.2 & 193.4 & 166.4 & 490.0 & 134.2 & 205.6 & 176.3 & 510.1 \\
\hline \multicolumn{2}{|c|}{2000} & 127.6 & 189.9 & 163.2 & 380.7 & 132.6 & 200.5 & 171.4 & 504.5 \\
\hline \multicolumn{2}{|c|}{4000} & 124.1 & 185.6 & 159.9 & 469.7 & 128.6 & 195.4 & 165.8 & 489.8 \\
\hline \multicolumn{2}{|c|}{6000} & 120.6 & 180.2 & 152.3 & 453.1 & 123.5 & 187.3 & 158.3 & 469.1 \\
\hline \multicolumn{2}{|c|}{ L.S.D at $5 \%$} & 7.36 & 8.13 & 5.34 & --- & 6.85 & 11.38 & 6.20 & --- \\
\hline \multicolumn{10}{|c|}{ Interactions : } \\
\hline \multicolumn{2}{|c|}{ Control * } & 120.5 & 188.4 & 170.3 & 479.2 & 130.7 & 198.7 & 160.5 & 489.9 \\
\hline \multirow{3}{*}{$\begin{array}{l}(2000 \\
+\mathrm{EM}) \\
\end{array}$} & Nov. & 129.6 & 197.3 & 179.8 & 506.7 & 138.9 & 207.6 & 169.9 & 516.4 \\
\hline & Ask. & 132.7 & 201.6 & 183.7 & 518.0 & 142.8 & 211.8 & 173.8 & 528.4 \\
\hline & Nov. + Ask & 139.8 & 209.7 & 191.6 & 541.1 & 149.6 & 218.7 & 180.9 & 549.2 \\
\hline \multirow{3}{*}{$\begin{array}{r}(4000 \\
+\mathrm{EM})\end{array}$} & Nov. & 127.5 & 195.4 & 177.6 & 500.5 & 136.7 & 205.4 & 167.8 & 509.9 \\
\hline & Ask. & 130.5 & 198.7 & 180.6 & 509.8 & 140.1 & 209.6 & 170.7 & 520.4 \\
\hline & Nov. $+A$ & 135.7 & 205.6 & 185.3 & 526.6 & 145.5 & 212.6 & $\begin{array}{l}175.6 \\
\end{array}$ & 533.7 \\
\hline \multirow{3}{*}{$\begin{array}{r}(6000 \\
+ \text { EM) }\end{array}$} & Nov. & 125.4 & 190.3 & 171.4 & 487.1 & 134.6 & 200.3 & 163.5 & 498.4 \\
\hline & Ask. & 126.9 & 196.2 & 176.3 & 499.4 & 138.1 & 205.2 & 170.5 & 513.8 \\
\hline & Nov. $+\mathrm{A}$ & 130.6 & 197.4 & 180.2 & 508.2 & 141.6 & 206.3 & 172.3 & 570.2 \\
\hline \multicolumn{2}{|c|}{ L.S.D at $5 \%$} & 8.13 & 9.22 & 6.07 & --- & 5.17 & 10.54 & 8.55 & --- \\
\hline
\end{tabular}

Table (3): Dry weight of herb of Majorana hortensis, Mnch. as affected by saline irrigation water, some nutritional compounds and their interactions during 2006/2007 and 2007/2008 seasons.

\begin{tabular}{|c|c|c|c|c|c|c|c|c|c|}
\hline \multirow{3}{*}{\multicolumn{2}{|c|}{ Treatments }} & \multicolumn{8}{|c|}{ Dry weight of herb (g/plant) } \\
\hline & & \multicolumn{4}{|c|}{ 1st season $2006 / 6007$} & \multicolumn{4}{|c|}{ 2nd season $2007 / 2008$} \\
\hline & & \multicolumn{3}{|c|}{\begin{tabular}{|l|l|l|} 
1st cut 2 nd cut 3 rd cut \\
\end{tabular}} & \multirow[t]{2}{*}{ Total } & \multicolumn{3}{|c|}{ 1st cut|2nd cut|3rd cut } & \multirow{2}{*}{ Total } \\
\hline \multicolumn{8}{|c|}{ Salinity (ppm) } & & \\
\hline \multirow{2}{*}{\multicolumn{2}{|c|}{ Control * }} & 27.13 & 41.14 & 36.17 & 104.44 & 8.55 & 43.74 & 37.51 & 109.80 \\
\hline & 2000 & 26.68 & 40.12 & 34.23 & 101.03 & 28.11 & 42.66 & 36.47 & 107.24 \\
\hline \multicolumn{2}{|c|}{4000} & 26.42 & 39.46 & 33.22 & 99.10 & 27.36 & 41.57 & 35.28 & 104.27 \\
\hline \multicolumn{2}{|c|}{6000} & 25.66 & 38.34 & 32.40 & 96.40 & 26.27 & 39.85 & 33.68 & 99.80 \\
\hline \multicolumn{2}{|c|}{ L.S.D at $5 \%$} & 3.96 & 6.27 & 2.17 & --- & 2.75 & 5.45 & 3.87 & --- \\
\hline \multicolumn{10}{|c|}{ Interactions } \\
\hline \multicolumn{2}{|c|}{ Control * } & 25.64 & 40.09 & 35.48 & 101.21 & 27.81 & 42.28 & 34.15 & 104.24 \\
\hline \multirow{3}{*}{$\begin{array}{c}(2000+ \\
\text { EM) }\end{array}$} & Nov. & 27.57 & 41.98 & 38.26 & 107.81 & 29.24 & 43.71 & 35.77 & 108.72 \\
\hline & Ask. & 28.23 & 42.44 & 38.67 & 109.34 & 30.38 & 44.59 & 36.59 & 111.56 \\
\hline & Nov. + Ask & 29.43 & 44.15 & 40.34 & 113.92 & 31.49 & 45.95 & 38.08 & 115.52 \\
\hline \multirow{3}{*}{$\begin{array}{l}(4000 \\
+\mathrm{EM})\end{array}$} & Nov. & 26.84 & 40.96 & 37.39 & 105.19 & 28.78 & 43.15 & 35.25 & 107.18 \\
\hline & Ask. & 27.47 & 41.83 & 38.02 & 107.32 & 29.49 & 44.13 & 35.94 & 109.56 \\
\hline & Nov. + Ask & 28.57 & 43.28 & 39.01 & 110.86 & 30.63 & 44.76 & 36.97 & 112.36 \\
\hline \multirow{3}{*}{$\begin{array}{l}(6000 \\
+\mathrm{EM})\end{array}$} & Nov. & 26.40 & 40.06 & 36.08 & 102.54 & 28.34 & 42.17 & 34.42 & 104.93 \\
\hline & Ask. & 26.72 & 41.31 & 37.12 & 105.15 & 29.07 & 43.20 & 35.89 & 108.16 \\
\hline & Nov. + As & 27.49 & 41.56 & 37.93 & 106.98 & 29.81 & 43.43 & 36.27 & 109.51 \\
\hline \multicolumn{2}{|c|}{ L.S.D at $5 \%$} & 2.10 & 8.90 & 3.54 & --- & 3.07 & 7.51 & 4.48 & --- \\
\hline
\end{tabular}

The effect of saline irrigation water and both of Novatrein, Askobein and EM1 interactions are indicated in Tables 2 and 3. Data showed that the lower or moderate concentration of salinity (2000 or $4000 \mathrm{ppm})$ and all the used of different structures caused an increase in fresh and dry weight of marjoram 
plants comparing with general control or salinity treatments solely. While increasing salinity concentration in irrigation water at $6000 \mathrm{ppm}$ combined with any of previous structures decreased both herb fresh and dry weights per plant and per plot compared with control plants in the two seasons.

The enhancing effect of interaction treatments between the used structures and the low or moderate saline water level (2000 or $4000 \mathrm{ppm}$ ) on fresh and dry weights of herb marjoram might attributed, some extent, to some trace elements, i.e. $\mathrm{Fe}, \mathrm{Mn}$ and $\mathrm{Zn}$ besides some organic acids and microorganisms which reduced the harmful effect of salt stress due to their enhancing effect on the metabolic process (anabolism) causing stimulation of vegetative growth, consequently more herb weight. On the other hand, the highest level of salinity (up to $6000 \mathrm{ppm}$ ) might inhibit the most physiological processes, in addition to toxic effect of certain ions which may be absorbed by plant roots causing adverse effect on herb growth.

2. Effect of saline irrigation water, EM1, Novatrein, Askobein and their interactions on survival percentage of marjoram plants(\%):

The concerned results in Table (4) indicated a gradual decrease in survival percentage as the level of water salinity increased, since at 6000 ppm level most plants were died (50.0, 45.0 and 45.0) and (48.0, 45.0 and 43.0) respectively at three cuts in both seasons compared with control plants. Otherwise, under $2000 \mathrm{ppm}$ the treated plants showed a good tolerance and gave a slight decrease in the two seasons. These results agreed with those obtained by Massoud et al., (2002) on thyme plants and Shalan et al., (2006) on marjoram plants. They reported that salinity treatments resulted in a considerable decrease in survival percentage.

The reduction in survival percentages under salinity stress might be attributed to osmotic inhibition of water absorption, toxicity of one or more specific ions and/or the combination of the two factors. These in turn could disrupt survival physiological processes in plants leading to reduction in growth and its ability of salinity tolerance consequently more reduction in survival percentage, (Lapina, 1967).

With respect to structure of EM and both of Novatrein and Askobein, the same table proved that previous structures resulted in an increment in survival percentage and such increment was the best value at application of Novatrein, EM1, Askobein, respectively in both seasons, comparing with control. Such results are agreement with those obtained by Ramadan (1996) on guar.

The interaction effect in this respect was also revealed in Table (4). From this Table, it was showed that under the highest saline water concentration $(6000 \mathrm{ppm})$, the plants could not tolerate the salt stress and showed the lowest survival percentage (50.0, 45.0 and 45.0) and (48.0, 45.0 and 43.0) respectively at the three cuts in both seasons. Whereas spraying plants with EM + Novatrein or EM + Askobein recorded slight increase. Moreover, increasing interactions EM + Novatrein + Askobein were the most effective to raise survival percentage comparing with unsprayed plants in both seasons. On the other side, the plants showed good tolerance to salinity at $2000 \mathrm{ppm}$. At the moderate salinity concentration (4000 ppm) were [85.0, 84.0 and $80.0 \%]$ and $[86.0,84.0$ and $80.0 \%]$ respectively in the first and 
second seasons. The used mixture of bio_compunds ( EM+ Novatrein + Askobein) enhanced salinity tolerance were[90.0, 89.0 and $89.0 \%]$ and [91.0, 90.0 and $89.0 \%$ respectively, in the first and second seasons .

They raised survival percentage from to. Our results herein agreed with Ramadan (1996) on guar, who raised survival percentage of salinity plants by using mixtures of trace-elements.

Moreover, this reduction of survival percentage under salinity stress might be due to the salt damage in the early stage of seedlings or toxic effect during the growth season, Stone et al.,(1979), while the enhancing effect of microorganisms and iron, manganese and zinc application on salinity tolerance might be helped the treated plants to overcome the harmful effects of salinity stress.

Table (4): Survival percentage (\%) of Majorana hortensis ,Mnch. as affected by saline irrigation water, some nutritional compounds and their interactions during 2006/2007 and 2007/2008 seasons.

\begin{tabular}{|c|c|c|c|c|c|c|}
\hline \multirow{3}{*}{ Treatments } & \multicolumn{6}{|c|}{ Survival percentage (\%) } \\
\hline & \multicolumn{3}{|c|}{ 1st season $2006 / 6007$} & \multicolumn{3}{|c|}{ 2nd season $2007 / 2008$} \\
\hline & 1st cut & 2nd cut & 3rd cut & 1st cut & 2nd cut & 3rd cut \\
\hline \multicolumn{7}{|l|}{ Salinity (ppm) } \\
\hline Control * & 100.00 & 100.00 & 99.00 & 100.00 & 99.00 & 99.00 \\
\hline 2000 & 97.00 & 97.00 & 95.00 & 97.00 & 96.00 & 96.00 \\
\hline 4000 & 85.00 & 84.00 & 80.00 & 86.00 & 84.00 & 80.00 \\
\hline 6000 & 50.00 & 45.00 & 45.00 & 48.00 & 45.00 & 43.00 \\
\hline L.S.D at $5 \%$ & 25.31 & 18.25 & 19.08 & 32.31 & 22.13 & 16.71 \\
\hline
\end{tabular}

\begin{tabular}{|c|c|c|c|c|c|c|c|}
\hline \multicolumn{2}{|c|}{ Control * } & 100.00 & 100.00 & 99.00 & 100.00 & 99.00 & 99.00 \\
\hline \multirow{3}{*}{$\begin{array}{r}(2000 \\
+E M)\end{array}$} & Nov. & 97.90 & 96.00 & 96.00 & 97.90 & 95.70 & 95.00 \\
\hline & Ask. & 98.53 & 97.00 & 97.00 & 98.50 & 96.90 & 96.00 \\
\hline & Nov. + Ask & 99.60 & 99.60 & 99.40 & 99.00 & 99.80 & 98.50 \\
\hline \multirow{3}{*}{$\begin{array}{l}(4000 \\
+\mathrm{EM})\end{array}$} & Nov. & 87.03 & 88.00 & 85.50 & 86.00 & 85.50 & 85.00 \\
\hline & Ask. & 89.00 & 88.80 & 88.00 & 88.00 & 87.60 & 87.00 \\
\hline & Nov. + Ask & 90.00 & 89.70 & 89.00 & 91.00 & 90.00 & 89.00 \\
\hline \multirow{3}{*}{$\begin{array}{l}(6000 \\
+\mathrm{EM})\end{array}$} & Nov. & 65.50 & 65.40 & 64.00 & 68.00 & 66.00 & 65.00 \\
\hline & Ask. & 70.30 & 70.00 & 69.00 & 73.00 & 72.00 & 70.00 \\
\hline & Nov. + Ask & 78.60 & 78.00 & 76.00 & 82.00 & 82.00 & 80.00 \\
\hline \multicolumn{2}{|c|}{ L.S.D at $5 \%$} & 27.06 & 20.07 & 24.15 & 33.20 & 24.81 & 19.45 \\
\hline
\end{tabular}

3. Effect of saline irrigation water, some nutritional compounds and their interactions on essential oil percentage of marjoram plants (\%):

The data in Table (5) clear that plants irrigated with the lower level of saline water proved slight increment of essential oil percentage in dry herb. On the other hand, increasing salinity levels up to $4000 \mathrm{ppm}$ or $6000 \mathrm{ppm}$ resulted in a decrease essential oil percentage compared with control. The lowest value was by using $6000 \mathrm{ppm}$ salinity concentration [1.54, 1.30 and $1.13 \%]$ and [1.63, 1.38 and $1.14 \%]$ respectively, during the first and second seasons. Similar results were previously recorded by Shalan et al., (2006) on marjoram plants.

The reduction in oil percentage was expected as a result of adverse effects of saline water on vegetative growth characters. Also, salt stress 
might be disrupt several physiological process in plants leading to reduction in essential oil production, (Trease, 1966). In the same time, Penk (1978) reported that the formation and accumulation of essential oils in plants due to the action of environmental factors.

Results presented in Table (5) also indicate that application marjoram plants with bio_compounds of EM1 and both of Novatrein and Askobein were effective in enhancing essential oil percentage comparing to the control in both seasons. The superior in this regard was the interaction treatment of spraying were EM + Novatrein + Askobein followed by EM + Askobein and EM1 + Novatrein, respectively, in both seasons. Similar findings were previously recorded by Morsy (1999) on Thymus vulgaris.

Accordingly, the interaction between EM1 and both of Novatrein and Askobein, combined with the lowest salinity water level (2000 ppm) was the best to produce the highest percentage of essential oil in both seasons. Such results proved that the applied constituents of mentioned compounds especially microorganisms, trace-elements and organic acids, beside Macroelements could be counteracted the depressive effect of irrigation water salinity on herb essential oil.

Table(5): Essential oil percentage of dry herb (\%) of Majorana hortensis, Mnch as affected by saline irrigation water, some nutritional compounds and their interactions during 2006/2007 and 2007/2008 seasons.

\begin{tabular}{|c|c|c|c|c|c|c|c|}
\hline \multirow{3}{*}{\multicolumn{2}{|c|}{ Treatments }} & \multicolumn{6}{|c|}{ Oil percentage (\%) } \\
\hline & & \multicolumn{3}{|c|}{ 1st season $2006 / 6007$} & \multicolumn{3}{|c|}{ 2nd season $2007 / 2008$} \\
\hline & & $1^{\text {st }}$ cut & $2^{\text {nd }}$ cut & $3^{\text {rd }}$ cut & $1^{\text {st }}$ cut & $2^{\text {nd }}$ cut & $3^{\text {rd }}$ cut \\
\hline \multicolumn{8}{|l|}{ Salinity (ppm) } \\
\hline \multicolumn{2}{|c|}{ Control * } & 1.92 & 1.83 & 1.61 & 1.94 & 1.72 & 1.52 \\
\hline \multicolumn{2}{|c|}{2000} & 1.79 & 1.75 & 1.52 & 1.82 & 1.64 & 1.43 \\
\hline \multicolumn{2}{|c|}{4000} & 1.62 & 1.38 & 1.20 & 1.71 & 1.50 & 1.20 \\
\hline \multicolumn{2}{|c|}{6000} & 1.54 & 1.30 & 1.13 & 1.63 & 1.38 & 1.14 \\
\hline \multicolumn{8}{|l|}{ Interactions: } \\
\hline \multicolumn{2}{|c|}{ Control * } & 1.69 & 1.68 & 1.50 & 1.68 & 1.65 & 1.60 \\
\hline \multirow{3}{*}{$\begin{array}{l}(2000 \\
+ \text { EM) }\end{array}$} & Nov. & 1.75 & 1.73 & 1.62 & 1.87 & 1.78 & 1.65 \\
\hline & Ask. & 1.85 & 1.81 & 1.72 & 1.95 & 1.90 & 1.80 \\
\hline & Nov. + Ask & 1.98 & 1.88 & 1.80 & 2.21 & 2.00 & 1.95 \\
\hline \multirow{3}{*}{$\begin{array}{l}(4000 \\
+ \text { EM) }\end{array}$} & Nov. & 1.72 & 1.70 & 1.55 & 1.73 & 1.68 & 1.66 \\
\hline & Ask. & 1.88 & 1.76 & 1.61 & 1.87 & 1.80 & 1.70 \\
\hline & Nov. + Ask & 1.88 & 1.80 & 1.75 & 1.90 & 1.85 & 1.80 \\
\hline \multirow{3}{*}{$\begin{array}{l}(6000 \\
+ \text { EM) }\end{array}$} & Nov. & 1.70 & 1.69 & 1.52 & 1.69 & 1.66 & 1.62 \\
\hline & Ask. & 1.68 & 1.60 & 1.50 & 1.69 & 1.58 & 1.49 \\
\hline & Nov. + Ask & 1.79 & 1.73 & 1.62 & 1.78 & 1.65 & 1.58 \\
\hline
\end{tabular}

4. Effect of saline irrigation water, some nutritional compounds and their interactions on. chemical structure of essential oil of marjoram plants (\%):

Gas Liquid Chromatography determination separation analysis (G.L.C) was used to dermin the components of the essential oil marjoram produced from $2^{\text {nd }}$ in the second season. The results of analysis are shown in Table (6) and Fig(1-4). 
J. Agric. Sci. Mansoura Univ., 34 (5), May, 2009

T6

5043 

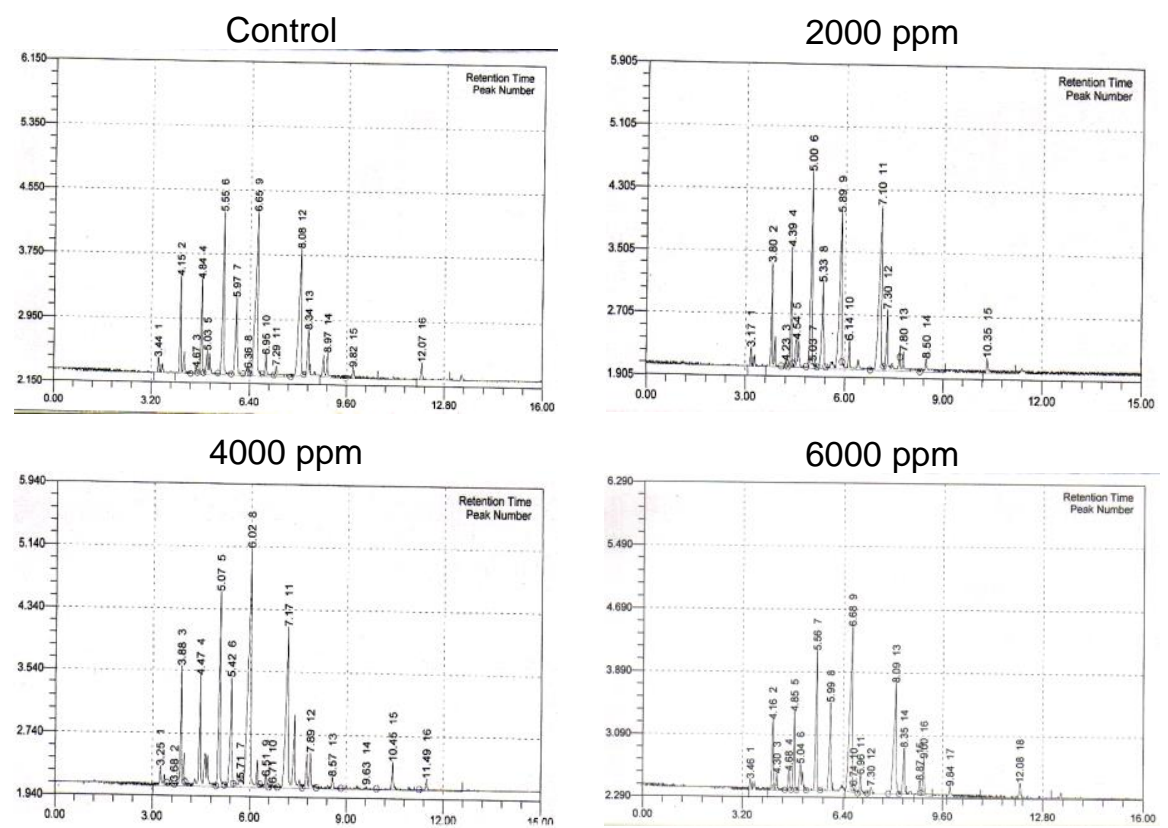

Figs. (1): Main constituents of marjoram essential oil as affected by salinity 2000,4000 and $6000 \mathrm{ppm}$ during the second season of 2007/2008.

Effect of saline irrigation water indicated that the hydrocarbons percentages were $23.68 \%$ and the oxygenated compounds recorded 63.94 $\%$. Comparing sush value with those under salinity levels, it could be observed that some oil constituents were decreased or disappeared.

The major hydrocarbons was terpinene-4-ol, which was decreased with 2000 and 4000 ppm salinity levels. While, the highest salinity level (6000)was more effective in this regardl

The main oxygenated compound was linalyl-acetate, which increased as salinity level increased. Both linalool and eugenol were decreased to be the lowest with increasing salinity levels.

The reduction in main components of essential oil of marjoram plants was excepting owing to the opposite stress of salinity water levels on biosynthetic reactions of volatile oil.

Otherwise, compounds of EM and both of Novatrein and Askobein, because of its contents of microorganisms, macro-elements, some organic acids and trace-elements i.e., iron, manganese and zinc caused enhancing effect in main active principles of volatile oil of marjoram plants. Variation in the essential oil constituents under salinity treatments agreed with those obtained by Massoud et al.,(2002) on Thymus vulgaris,and Shalan et al.,(2006) on marjoram. 

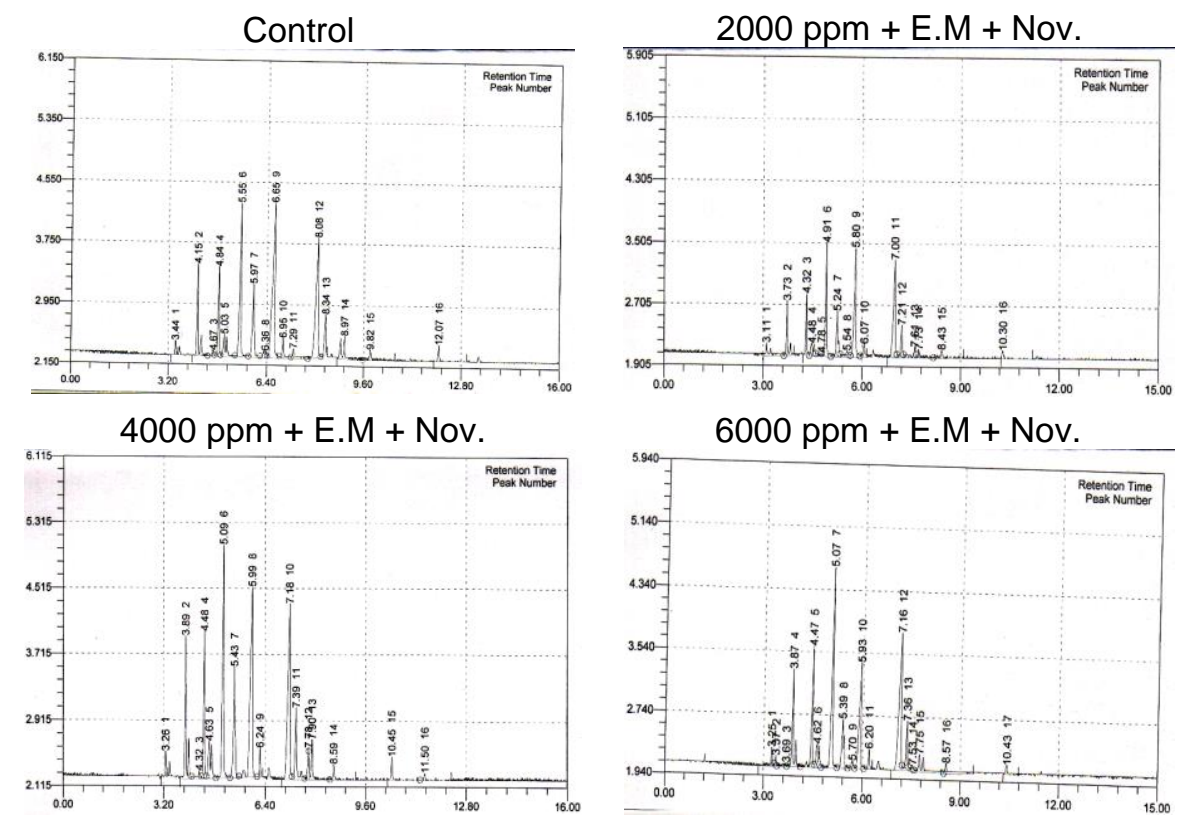

Figs. (2): Main constituents of marjoram essential oil as affected by the interaction of salinity at 2000, 4000 and 6000 ppm with E.M and Novatrein during the second season of 2007/2008
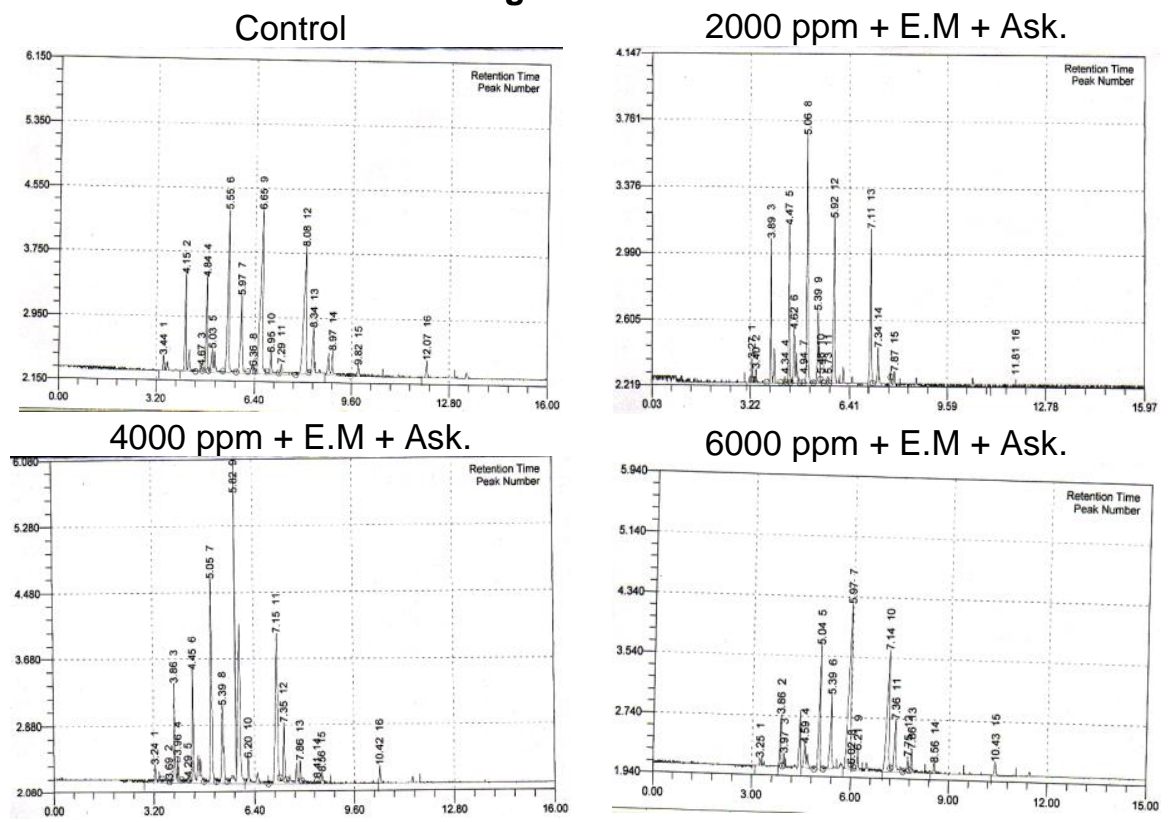

Figs.(3): Main constituents of marjoram essential oil as affected by the interaction of salinity at 2000,4000 and 6000 ppm with E.M and Askobein during the second season of 2007/2008. 

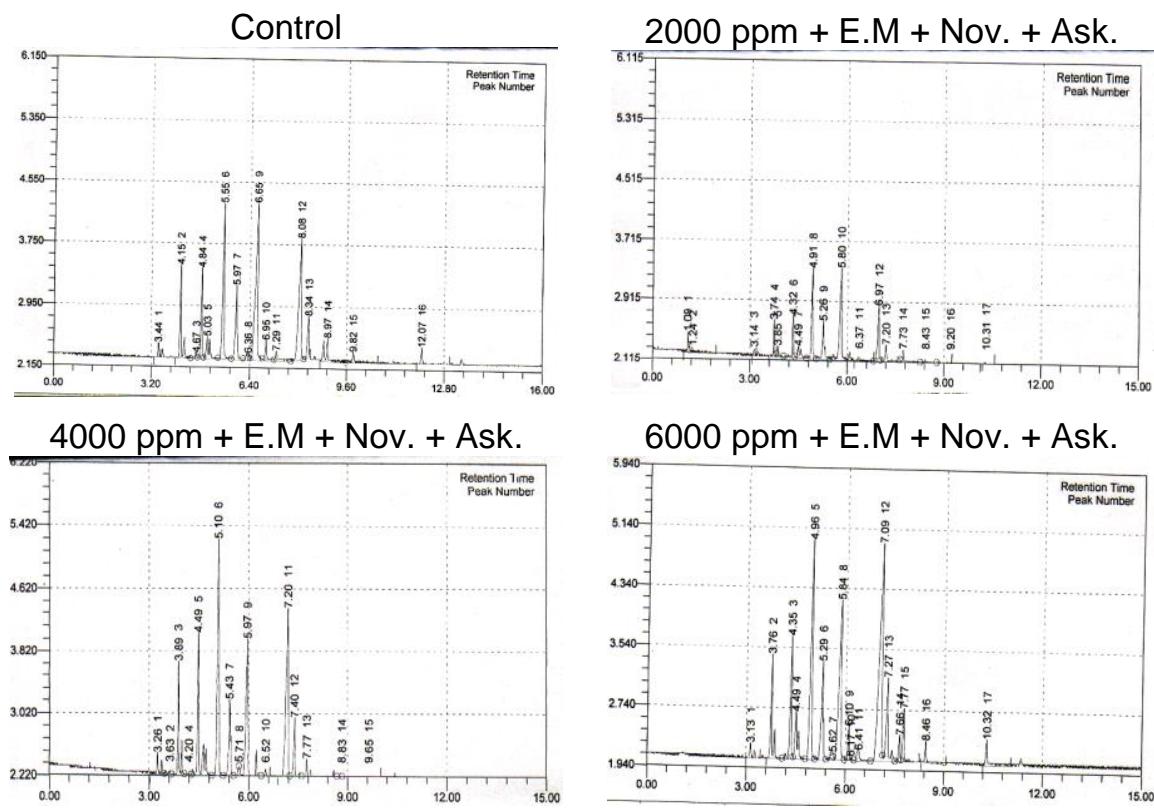

Figs.(4): Main constituents of marjoram essential oil as affected by the interaction of salinity at 2000, 4000 and 6000 ppm with E.M, Novatrein and Askobein during the second season of 2007/2008.

\section{Recommendation}

Marjoram plants can be tolerated saline irrigation water level up to 2000 ppm without significant reduction in most characters. Otherwise, the level up to $6000 \mathrm{ppm}$ caused reduction in the growth, oil percentage(\%) and the main components of essential oil.

Spraying marjoram plants with (EM), Novatrein or Askobein caused increasing growth and essential constitutes and the highest values realized at application $\left(E_{1}\right)+$ Novatrein+Askobein, $(E M)+$ Askobein and $(E M)+$ Novatrein, respectively. The interaction treatment between $2000 \mathrm{ppm}$ salinity level and $\left(E M_{1}\right)+$ Novatrein + Askobein recorded the highest values concerning growth and essential oil constituents.

Accordingly, could be overcome the harmful effect of saline water level up to $4000 \mathrm{ppm}$ by spraying marjoram plants with compounds $\left(E_{1}\right)+$ Novatrein + Askobein.

\section{REFERENCES}

Abd EL-Kafie, Omaima M. (1995). Effect of salinity and cycocel on Salvia officinalis L. J. Agric. Sci. Mansoura Univ., 20(1): 377-385.

Abd EL-Messeih, W.M.;Amal M. El-Seginy and H.Kabeel. (2005). Effect of EM biostimulant on growth and fruiting of Le Conte pear trees in newly reclaimed areas. Alex.Sci.Exc.J.(2): 121-128. 
Egyptian Pharmacopoeia (1984): Egyptian Pharmacopoeia, General Organization for Government. Printing Office, Ministry of Health, Cairo,Egypt,p.31-33.

El-Queseni, F.E.M. and S.H. El-Gayar (1993). Effect of salinity and Eptam herbicide on some agronomic characters and chemical composition of sunflower. Zagazig. J. Agic. Res., 20 (2A): 623-631.

Guenther, E. (1961). "The Essential Oils". D. Van. Nostrand Comp., New York, Tornato, London vol. 1.

Guenther, Z. and S. Joseph (1978). Handbook Series in Chromatography. GRC Press Inc.

Harridy, I.M.A. (1986). Physiological studies on periwinkle plants. Ph. D. Thesis, Fac. Agric.Cairo Univ.

Hasegawa, P.M.; R.A. Bressan and A.K. Handa (1986). Cellular mechanisms of salinity tolerance. Hort. Sci., 21:1317.

Hussein, A.B. (1999).Physiological studies on the effect of soil salinity on sweet basil plants. M.Sc. Thesis, Fac. Agric., Zagazig Univ.

Kandeel, A.M. and I.M. Elwan (1991). Effect of water salinity on the growth and the chemical composition of marjoram plants ( Majorana hortensis, Monch). 1. Effect of salinity on the plant growth. Annala Agric. Sci., Ain Shams Univ., Cairo, 36 (2): 583-588.

Lapina, L.P. (1967). Effect of high isosomotic concentrations of $\mathrm{NaCl}$ and dextrin on horse bean plant. Plant Physio., 141:241-319.

Makarim, A.M. and G.A.A. Bishr (1988). Effect of micronutrient element spraying on growth, yield and oil production of Matricaria chamomilla, L. Zagazig. J. Agric. Res., 15(2): 396-410.

Mandour, M.S.; A.S. Radwan and S.A. Ibrahim (1979). Combined effect of salinity and chlromequat application on Ammi Majus,L. Plant. 1. Growth fruiting and comarin content. Proc. $3^{\text {rd }}$ Arab Pest Conf., Tanta Univ.,

Massoud, Hekmat, Y.; M. Sharaf EL-Din; R. Hassan and A. Ramadan (2002). Effect of salinity and some trace-elements on growth and leaves essential oil content of thyme (Thymus vulgaris, L.) plants. $2^{\text {nd }}$ Inter. Conf. Hort. Sci., Kafr EL-Sheikh, Tanta Univ., Egypt.

Morsy, A.M.K. (1999). Physiological studies on growth and volatile oil yield of Thymus vulgaris L. plant. Ph. D. Thesis, Fac. Agric., Mansoura Univ.

Omar, F.A.; M.Abd El-Rahim; A.S. El-Ball and M.S. El-Shourbagy (1983). Optimization of fruit yield components in Anise Pimpinella anisum. J. Micronutrients Jreme Symposium International des Plants condiment aires et medicinales. Angres France, 27 Mai.(1983)

Penk, M. (1978). Influence of irrigation on the contents of effective substances in official plants. Acta Horticulturae, 73:181-198.

Ramadan, A.A.(1996). Effect of salinity and some elements on guar. M.Sc. Thesis, Fac.Agric, Zagazig Univ.

Sangakkara, U.R. (1999). Root dynamics and nutrient uptake efficiencies of mung bean as affected by organic matter and effective micro organisms,.Fifth International Conference on Kyusei Nature Faming.Faculty of Agricultural, Univ. of Peradeniya, ri Lanka. pp. 182193. (C.F Field Crop Abst. 53:4798;2000). 


\section{Massoud, Hekmat Y. et al.}

Shalan, M.N.; T.A.T. Abdel-Latif and E.A.E. EL-Ghadban (2006). Effect of water salinity and some nutritional compounds on the growth and production of sweet marjoram (Majorana hortensis, L.) plants. Egypt. J. Agric. Res., 84(3):959-975.

Steel, R.G. and J.H. Torrie (1980). Principles and Procedures of Statistics. M.C. Grow Hill Book Company Inc. New York (N.H.S.D.), London.

Stone, J.E; D.B. Marx and A.K. Dobrenz(1979). Interaction of sodium chloride and temperature on germination of two alfalfa cultivars. Agron. J., 71(5-6):425-427.

Trease, G.E.(1966). A Text Book of Pharmacognosy.Baillier, Trindall and Cassell,London.

\section{تأثيرالملوحسة وبعض المركبـات الحيويـه علـي النمـو و محصـول الزيـــ الطيـار و

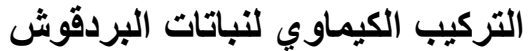

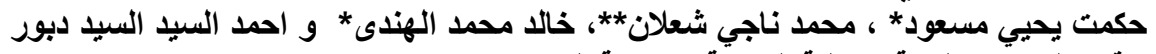

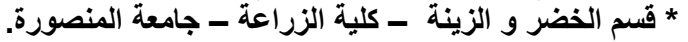 * مركز البحوث الزراعيةـ معهل بحوث البساتينـ قسم بحوث النباتات الطبية والعطرية.}

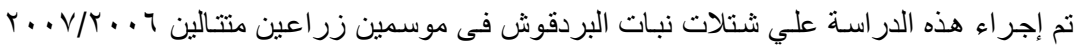

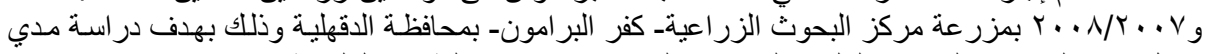

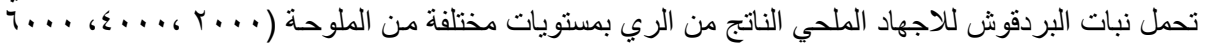

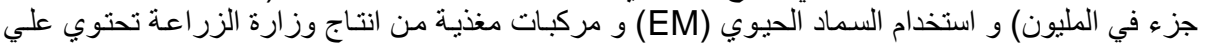

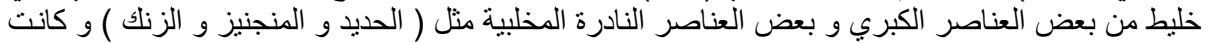

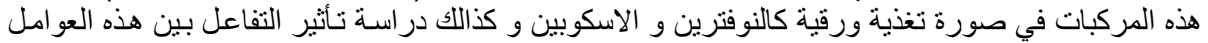

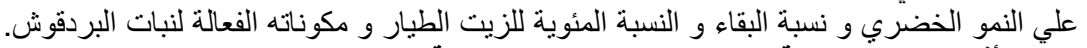

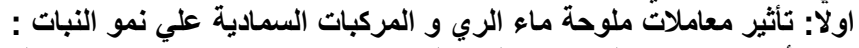

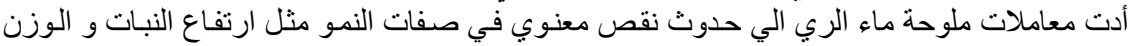

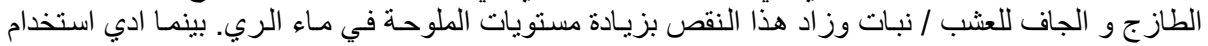

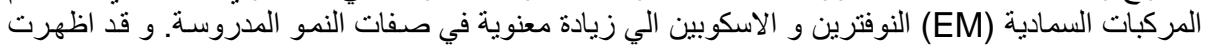

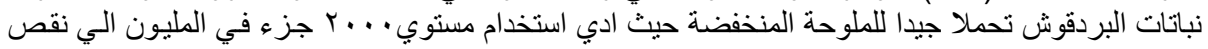

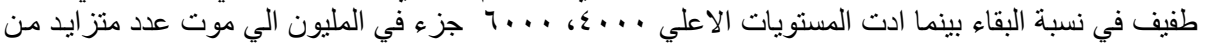

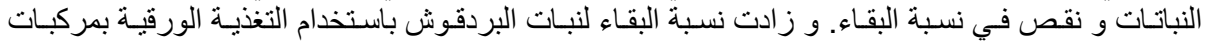

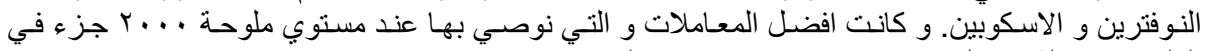

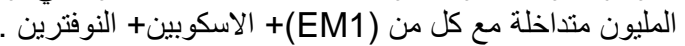

ثانيا: تأثير معاملات ملوحة ماء الري و المركبات السمادية علي النسبة المئوية و مكونـات و جودة الزيت

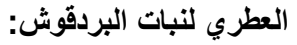

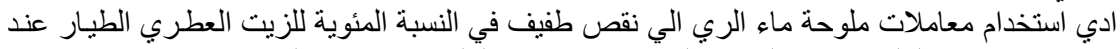

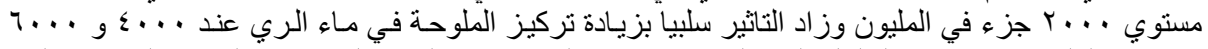

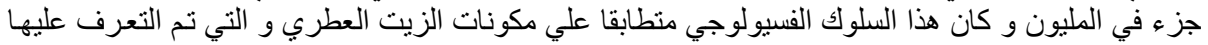

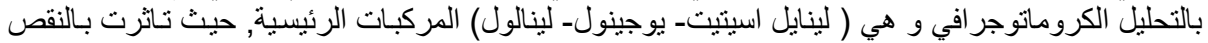

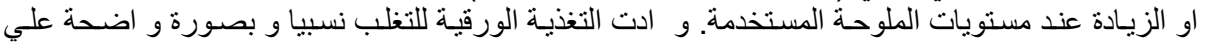

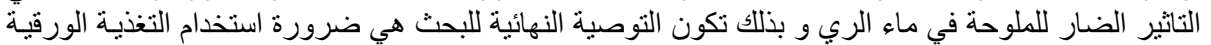

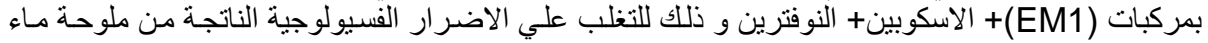
الري تحت ظروف منطقة الزر اعة. 
Table (6): The percentages of components of Majorana hortensis Mnch as affected by saline irrigation water, some nutritional compounds and their interactions during 2006/2007 and 2007/2008 seasons.

\begin{tabular}{|c|c|c|c|c|c|c|c|c|c|c|c|c|c|}
\hline \multirow{2}{*}{ Treatments } & \multicolumn{4}{|c|}{ Salinity levels (ppm) } & \multicolumn{3}{|c|}{$\begin{array}{c}\text { Salinity levels }(\mathrm{ppm})+\mathrm{EM}+ \\
\text { Novatrein }\end{array}$} & \multicolumn{3}{|c|}{$\begin{array}{c}\text { Salinity levels (ppm) }+ \text { EM + } \\
\text { Askobein }\end{array}$} & \multicolumn{3}{|c|}{$\begin{array}{l}\text { Salinity levels (ppm) + EM + } \\
\text { Nov. + Ask. }\end{array}$} \\
\hline & Control & 2000 & 4000 & 6000 & $\begin{array}{c}2000+ \\
\text { EM+ Nov. }\end{array}$ & $\begin{array}{c}4000+E M \\
+ \text { Nov. }\end{array}$ & $\begin{array}{c}6000+ \\
E M+\text { Nov. }\end{array}$ & $\begin{array}{c}2000+ \\
\text { EM+ Ask. }\end{array}$ & $\begin{array}{c}4000+ \\
E M+A s k\end{array}$ & $\begin{array}{c}6000+ \\
E M+ \\
\text { Ask. }\end{array}$ & $\begin{array}{c}2000+ \\
\text { EM+ } \\
\text { Nov.+ } \\
\text { Ask. }\end{array}$ & $\begin{array}{c}4000+ \\
\text { EM Nov.+ } \\
\text { Ask. }\end{array}$ & $\begin{array}{c}6000+ \\
\text { EM+ } \\
\text { Nov.+ } \\
\text { Ask. }\end{array}$ \\
\hline 1. $\alpha$-pinene & 0.86 & 0.96 & 0.95 & 0.60 & 4.84 & 1.80 & 1.04 & 1.16 & 2.22 & 2.15 & 0.67 & 0.55 & 1.07 \\
\hline 2. $\beta$-pinene & 7.40 & 6.82 & 6.70 & 5.59 & 6.50 & 10.98 & 4.78 & 8.71 & 5.19 & 7.55 & 8.11 & 5.91 & 4.22 \\
\hline 3. Limonene & 0.72 & 0.43 & -- & 1.79 & 6.20 & 0.46 & 1.65 & 1.19 & 1.16 & 0.54 & 0.72 & 1.15 & -- \\
\hline 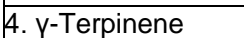 & 4.08 & 4.09 & 4.28 & -- & 0.87 & 7.14 & 4.26 & 4.74 & -- & -- & 4.00 & 4.68 & 4.56 \\
\hline 5. $\beta$-Caryophyllene & 2.45 & -- & 0.42 & 0.78 & 2.43 & -- & 0.95 & 1.32 & 2.78 & 1.37 & 1.75 & 2.49 & 1.40 \\
\hline 6. Terpinene-4-ol & 8.17 & 7.20 & 7.20 & 8.19 & 7.92 & 7.56 & 7.40 & 7.91 & 7.37 & 6.87 & 9.24 & 7.19 & 6.26 \\
\hline Hydrocarbons & 23.68 & 19.50 & 19.55 & 16.95 & 28.76 & 27.94 & 20.08 & 25.03 & 18.72 & 18.48 & 24.49 & 21.97 & 17.51 \\
\hline 7. Linalyl acetate & 22.02 & 18.76 & 27.76 & 25.87 & 24.95 & 18.81 & 13.96 & 19.81 & 31.98 & 17.25 & 25.13 & 15.02 & 12.30 \\
\hline 8. Linalool & 14.01 & 13.83 & 11.97 & 11.37 & 13.99 & 19.15 & 13.60 & 18.01 & 15.85 & 12.84 & 17.44 & 14.52 & 11.88 \\
\hline 9. 1,8 cineol & 6.60 & 6.60 & 11.03 & 5.73 & 3.60 & 9.68 & 6.56 & 7.69 & 9.53 & 13.74 & 6.47 & 9.11 & -- \\
\hline 10. $\alpha$-Terpinol & 1.46 & 0.96 & 0.47 & -- & 2.41 & 1.14 & -- & -- & -- & 1.04 & 1.06 & 1.06 & -- \\
\hline 11. Estragol & 2.51 & 4.21 & 1.91 & 1.14 & -- & -- & -- & -- & -- & -- & 0.46 & 0.20 & -- \\
\hline 12. Eugenol & 17.34 & 20.44 & 20.02 & 15.57 & 17.98 & 13.55 & 10.49 & 19.53 & 17.33 & 14.65 & 24.47 & 19.53 & 19.43 \\
\hline Oxygenated & 63.94 & 64.80 & 73.16 & 59.32 & 62.93 & 62.33 & 44.61 & 65.04 & 74.69 & 59.52 & 75.03 & 59.44 & 43.61 \\
\hline Unknown & 12.38 & 15.70 & 7.29 & 23.73 & 8.31 & 9.73 & 35.31 & 9.93 & 6.59 & 22.00 & 0.48 & 18.59 & 38.88 \\
\hline
\end{tabular}

